\title{
Jurist-Diction
}

Volume 4 No. 6, November 2021

\section{Kedudukan Hukum Dropshipper dalam Transaksi Jual Beli Online}

\author{
Belinda Dwi Tamara \\ belindadwitamara@yahoo.com \\ Universitas Airlangga
}

How to cite:

Belinda Dwi Tamara,

'Kedudukan Hukum

Dropshipper dalam Transaksi

Jual Beli Online' (2021) Vol. 4

No. 6 Jurist-Diction.

Histori artikel:

Submit 6 April 2021;

Diterima 15 Oktober 2021;

Diterbitkan 5 November 2021.

DOI:

10.20473/jd.v4i6.31844

p-ISSN: 2721-8392

e-ISSN: $2655-8297$

\begin{abstract}
Nowadays, online buying and selling transactions are becoming a trend for running a digital business. In marketing a product in the digital world, the role of a trade intermediary is needed to bridge the spread of information and / or specifications for a product widely from various groups, namely the dropship system. The existence of the dropshipper creates a legal relationship between the parties, namely the dropshipper with the seller and the dropshipper with the buyer. If the dropshipper manages to get a prospective buyer, the dropshipper orders the prospective buyer order from the supplier of the goods. It is the supplier of the goods who sends the product to the buyer on behalf of the dropshipper. Thus, it creates a legal position for the dropshipper and the dropshipper's accountability in the online buying and selling transaction process.
\end{abstract}

Keywords: The Dropshipping System; Online Buying and Selling Transaction; Responsibility; Intermediary Traders.

\begin{abstract}
Abstrak
Saat ini, transaksi jual beli online menjadi suatu trend untuk menjalankan suatu bisnis digital. Dalam pemasaran suatu produk didunia digital diperlukan peran perantara dagang guna menjembatani penyebaran informasi dan/atau spesifikasi suatu produk secara luas dari berbagai kalangan yaitu sistem dropship. Adanya dropshipper tersebut menimbulkan suatu hubungan hukum antar para pihak yaitu dropshipper dengan penjual dan dropshipper dengan pembeli. Jika pihak dropshipper berhasil mendapatkan calon pembeli, maka pihak dropshipper memesankan pesanan calon pembeli kepada supplier barang. Supplier baranglah yang mengirimkan produk tersebut kepada pembeli dengan atas nama pihak dropshipper. Dengan demikian, menimbulkan suatu kedudukan hukum bagi dropshipper dan tanggung gugat dropshipper dalam dari proses transaksi jual beli online.

Kata Kunci: Sistem Dropship; Transaksi Jual Beli Online; Tanggung Gugat; Perantara Dagang.
\end{abstract}

Copyright $(92021$ Belinda Dwi Tamara

\section{Pendahuluan}

Saat ini dunia perdagangan telah memasuki babak baru seiring dengan transisi dunia global yang memasuki era industri 4.0. Industri 4.0 merupakan sebuah konsep yang menggunakan komputer dan robot sebagai dasarnya serta kemajuan yang 
paling terasa dari industri 4.0 adalah internet. ${ }^{1}$ Kini internet tidak hanya berfungsi seperti dahulu namun telah meliputi berbagai aspek kehidupan manusia baik dari segi informasi, sosial media hingga perdagangan. Dalam perdagangan, internet digunakan sebagai transaksi jual beli dengan tanpa adanya tatap muka antara penjual dan pembeli yang dilakukan melalui sistem elektronik atau sering disebut dengan istilah transaksi digital (e-commerce). Hal tersebut berbeda halnya dengan transaksi jual beli konvensional yang mengharuskan bahwa setiap transaksi jual beli yang dilakukan adalah secara tatap muka antara penjual dan pembeli dalam satu lingkup wilayah. Semua jenis transaksi dalam e-commerce dengan adanya tanpa tatap muka antara penjual dan pembeli baik dalam satu wilayah maupun lain wilayah, sehingga yang menjadi dasar dari transaksi e-commerce adalah kepercayaan satu sama lain. ${ }^{2}$

Dalam kurun waktu 5 (lima) tahun dari tahun 2014 hingga tahun 2018 transaksi digital Indonesia semakin bertumbuh pesat hal ini didukung dengan data eMarketer menunjukkan bahwa transaksi e-commerce Indonesia mencapai Rp 25,1 triliun pada 2014 dan akan naik menjadi Rp 69,8 triliun pada 2016, dengan kurs rupiah Rp 13.200 per dolar Amerika dan demikian pula pada 2018, nilai perdagangan digital Indonesia akan terus naik menjadi Rp 144,1 triliun. ${ }^{3}$ Seperti di Indonesia telah tumbuh adanya bisnis-bisnis baru yang mencapai predikat startup unicorn antara lain Gojek, Traveloka, Tokopedia, Buka Lapak, Ovo, dan JD.id. Enam perusahaan tersebut mewakili berbagai bidang industri mulai dari transportasi hingga keuangan. Namun seluruhnya adalah produk digital.

Dari penjelasan trend diatas melahirkan model-model bisnis baru dan penelitian ini berfokus pada kajian hukum salah satu model bisnis baru yaitu dropship. Dropship adalah sebuah teknik untuk pemasaran online dimana para pelaku bisnis toko online atau penjual tidak perlu menyimpan persediaan barang

\footnotetext{
${ }^{1}$ Marcel Susanto, 'Apa Itu Revolusi Industri 4.0?' (18 Januari 2019) <https://www.zenius. net/blog/21104/revolusi-industri-4-0>, dikunjungi pada tanggal 02 September 2020.

2 Asnawi, Haris Faulidi, Transaksi Bisnis E-Commerce Persfektif Islam (Magistra Insania Press 2004).[15-17].

${ }^{3}$ Databoks, 'Transaksi E-Commerce Indonesia Naik 500\% Dalam 5 Tahun' (16 November 2016) <https://databoks.katadata.co.id/datapublish/2016/11/16/transaksi-e-commerce-indonesia-naik-500-dalam-5-tahun>, dikunjungi pada tanggal 25 Agustus 2020.
} 
banyak karena saat mendapatkan orderan dari konsumen, maka penjual langsung meneruskan orderan dan detail pengiriman kepada produsen, distributor atau supplier yang sudah bekerjasama dengan mereka. ${ }^{4}$ Sedangkan istilah untuk pelaku teknik bisnis ini adalah Dropshipper. Secara tidak langsung Dropshipper dapat dikatakan sebagai seorang salesman yang menjual barang milik perusahaannya kepada end user tanpa perlu memiliki produknya. ${ }^{5}$

Para pihak yang terlibat dalam transaksi digital khususnya dalam model bisnis dropship meliputi:

a. Produsen atau penjual barang atau supplier;

Produsen atau penjual barang atau supplier dalam hal ini hanya bertindak sebagai produksi suatu barang dimana tidak melakukan proses branding barang tersebut dan tidak berinteraksi secara langsung pada pembeli.

b. Pembeli atau konsumen;

Pembeli atau konsumen dalam hal ini tidak berinteraksi secara langsung pada produsen atau penjual barang dan tidak mengetahui darimana asal barang yang diperoleh tersebut. Berdasarkan Peraturan Menteri Perdagangan Republik Indonesia Nomor 32/M-Dag/Per/8/2008 tentang Penyelenggaraan Kegiatan Usaha Perdagangan dengan Sistem Penjualan Langsung selanjutnya disebut sebagai Permendag No. 32/M-Dag/Per/8/2008 Pasal 1 Angka 7 menjelaskan bahwa konsumen adalah setiap orang pemakai barang dan/atau jasa, baik untuk kepentingan diri sendiri, keluarga, orang lain, maupun makhluk hidup lain dan tidak untuk diperdagangkan.

c. Perantara antara produsen dengan pembeli yaitu pihak ketiga yang menawarkan atau membranding barang si penjual atau produsen dalam media sosial atau e-commerce kepada pembeli dengan mengambil keuntungan tanpa melakukan stok barang atau sering disebut sebagai dropshipper.

${ }^{4}$ Adi Nugroho, E-commerce Memahami Perdagangan di Dunia Maya Cet.1 (Informatika 2006).[9].

5 Mohammad Fadil, Kajian Yuridis Praktik Dropship Online Shop di Indonesia Dalam Perspektif Hukum Ekonomi Syariah, (2017) Skripsi, Program Sarjana Universitas Negeri Semarang.[21]. 
Para pelaku usaha dalam transaksi digital terdapat beberapa sebutan lain diantaranya adalah reseller. Reseller dan dropshipper sendiri berkompetisi dalam berebut pangsa pasar dunia digital. Namun, keduanya memiliki perbedaan pada teknis. Menurut R. Soekardono, hukum dagang adalah bagian dari hukum perdata pada umumnya, yakni yang mengatur masalah perjanjian dan perikatan-perikatan yang diatur dalam Buku III Burgerlijk Wetboek selanjutnya disebut sebagai BW. ${ }^{6}$ Hukum dagang dapat pula dirumuskan adalah serangkaian kaidah yang mengatur tentang dunia usaha atau bisnis dan dalam lalu lintas perdagangan. ${ }^{7}$ Keterkaitan antara hukum perdata dan hukum dagang tersebut disebut sebagai lex specialis derogate legi generalis. Sistem dropship dalam kegiatan bisnis masuk klasifikasi bidang usaha bisnis dalam arti kegiatan perdagangan (commerce). Dalam hukum dagang, hubungan keperantaraan dropship ini masuk dalam kategori pedagang perantara berdiri sendiri yang disebut komisioner. Pedagang perantara berdiri sendiri yakni pedagang yang tidak terikat dengan perjanjian kerja antara perusahaan yang barangnya dipasarkan oleh pedagang perantara ${ }^{8}$ Untuk itu kedudukan pedagang perantara tersebut bukanlah sebagai karyawan dan hubungan hukum produsen barang dengan pedagang perantara yaitu berdasarkan perjanjian keagenan atau distributor. ${ }^{9}$

Dengan adanya situs e-commerce tentu para pelaku usaha wajib membuat kontrak perdagangan secara online atau biasa disebut dengan kontrak digital atau kontrak elektronik. Kontrak elektronik dianggap sah, apabila:

a. Terdapat kesepakatan para pihak;

b. Dilakukan oleh subjek hukum yang cakap (yang berwenang mewakili) sesuai dengan ketentuan peraturan perundang-undangan;

c. Terdapat hal tertentu;

d. Objek transaksi tidak boleh bertentangan dengan peraturan perundangundangan, kesusilaan, dan ketertiban umum. ${ }^{10}$

${ }^{6}$ Sentosa Sembiring, Hukum Dagang Edisi Revisi Cetakan Keempat (PT. Citra Aditya Bakti 2015).[5].

${ }^{7}$ R. Soekardono, Hukum Dagang Indonesia (Soeroengan 1963).[6].

${ }^{8}$ Sentosa Sembiring, Op.Cit.[127].

${ }^{9}$ ibid.

${ }^{10}$ Peraturan Pemerintah Nomor 82 Tahun 2012 tentang Penyelenggaraan Sistem Dan Transaksi Elektronik sesuai Ketentuan Pasal 47.[2]. 
Dalam situs e-commerce luar maupun dalam negeri juga diwajibkan membuat kontrak perdagangan online dalam bahasa Indonesia. ${ }^{11}$ Hal tersebut sebagai bukti mengikat antara para pihak dengan melahirkan asas pacta sunt servanda dan asas consensus. Oleh karena itu, pada transaksi digital saat ini, eksistensi pedagang perantara semakin exist dipasaran sehingga perlu pengkajian terhadap kedudukan dan tanggung gugat dropshipper sebagai jembatan untuk lebih menyebarluaskan informasi suatu produk pada pangsa pasar era digital.

\section{Metode Penelitian}

Metode yang digunakan dalam penelitian ini adalah penelitian hukum yang dilakukan dengan cara meneliti bahan-bahan pustaka atau data-data sekunder belaka. Penelitian ini bersifat Yuridis Normatif, oleh karena didasarkan pada metode, sistematika dan pemikiran tertentu dengan tujuan mempelajari suatu atau beberapa gejala hukum tertentu dan menganalisisnya.

\section{Klasifikasi Dropshipper dalam Hubungan Keperantaraan}

Dalam menjalankan kegiatan usaha dan sebagai akibat dari perkembangan dunia perdagangan khususnya pada era digital saat ini, para pengusaha tidak lagi menjalankan usahanya seorang diri melainkan membutuhkan peran dari pihakpihak baik dari dalam perusahaan maupun dari luar perusahaan. Pembantupembantu dalam perusahaan adalah pelayan toko, pekerja keliling, pemimpin filial, pemegang prokurasi, dan manajer. ${ }^{12}$ Pembantu diluar perusahaan adalah agen, notaris, pengacara, makelar, komisioner, konsultan, akuntan, dan sebagainya. ${ }^{13}$ Semuanya tersebut disebut sebagai perantara yang tidak memerlukan modal besar dan merupakan kegiatan usaha dagang yang menguntungkan bagi para pihak karena bagi prinsipal hanya cukup menunjuk perantara dagang pada bagian pemasaran

\footnotetext{
${ }^{11}$ Erlangga Jumena, 'Ini Aturan yang Harus Dicermati Pebisnis Online' (22 Agustus 2014) $<$ https://money.kompas.com/read/2014/08/22/203200426/Ini.Aturan.yang.Harus.Dicermati.Pebisnis.Online $>$, dikunjungi pada tanggal 31 Agustus 2020.

${ }^{12}$ Andi Sri R.W., Buku Ajar Hukum Dagang (Mitra Wacana Media 2014).[21].

${ }^{13}$ ibid.
} 
dan bagi perantara hanya cukup menjadi pembantu dari luar perusahaan dalam memperoleh keuntungan. ${ }^{14}$ Dalam hal ini perantara tunduk pada peraturan tentang pemberian kuasa seperti yang diatur dalam Pasal 1792-1819 BW.

Perdagangan dunia digital telah melahirkan suatu model bisnis baru dalam hal ini juga membutuhkan peran perantara dalam kegiatan usaha yang disebut sebagai sistem dropship. Dropship adalah sebuah teknik pemasaran dimana penjual tidak menyimpan stok barang, dan jika penjual mendapatkan order, penjual tersebut langsung meneruskan order dan detail pengiriman barangnya ke distributor dan/atau supplier dan/atau produsen. ${ }^{15}$ Dalam sistem dropship terdapat beberapa keuntungan dan kerugian. Berikut benefits menurut Mark and Andrew antara lain: ${ }^{16}$
a. Less Capital is Required;
b. Easy to Get Started;
c. Low Overhead;
d. Flexible Location;
e. Wide Selection of Products;
f. Easy to Scale.

Adapun disadvantages dari sistem dropship: ${ }^{17}$
a. Low Margins;
b. Inventory Issues;
c. Shipping Complexities;
d. Supplier Errors.

Untuk pelaku usaha terkait sistem dropship dikenal dengan sebutan dropshipper. Dropshipper merupakan pelaku usaha yang tidak membutuhkan modal besar karena sistem bisnis yang dijalankan tersebut suatu bentuk modifikasi dari sistem transaksi digital. Menurut Mark and Andrew, "Dropshipping is a service not a role" it means dropshipper is not one of players listed in the supply chain because any of the three (manufacturer, wholesaler or retailer) can act as a dropshipper.

\footnotetext{
${ }^{14}$ I Ketut Oka S., 'Tanggung Jawab Pedagang Perantara Terhadap Pihak Ketiga Menurut Hukum Jual Beli’ (2014) Volume 3 Nomor 1 Jurnal Law Review.[72].

${ }^{15}$ Rico Huang dan Seno A. Airlangga, Menjual Barang Tanpa Tatap Muka Dropship Mastery (PT. Alona Indonesia Raya 2014).[14].

${ }^{16}$ Mark Hayes and Andrew Youderian, The Ultimade Guide to Dropshipping, 1 st edition, (Lulu Publishing Services 2013).[2-3].

${ }^{17}$ ibid.[3-4].
} 
Menjadi seorang dropshipper hanya perlu keterampilan dan kreatifitas untuk memasarkan barang yang tidak ada pada dirinya secara fisik dimana hanya berupa foto dan/atau katalog barang serta deskripsi atau spesifikasi barang yang telah ditentukan oleh produsen atau penjual barang. Produsen dan/ atau supplier dan/atau penjual suatu barang juga membutuhkan peranan dari para pelaku usaha dropshipper guna menjangkau pasar yang lebih luas. Setelah calon pembeli tertarik untuk membeli barang dari dropshipper tersebut, maka tugas dropshipper adalah langsung menginformasikan kepada produsen barang. Sebelumnya, pihak pembeli harus telah bertransaksi digital terlebih dahulu dengan pihak dropshipper kemudian barulah pihak dropshipper melakukan transaksi jual beli online dengan pihak produsen barang. Setelah semua proses transaksi pembayaran dilakukan oleh para pihak kemudian barulah pihak produsen dapat melakukan pengiriman barang kepada alamat pembeli dengan atas nama pihak dropshipper. Dalam hal perantara dagang, dropshipper masuk kedalam perantara yang tidak bertujuan atas akibat hukum dari perbuatan keperantaraannya yaitu komisioner.

Berdasarkan Pasal 76 KUHD, Komisioner adalah seseorang yang menyelenggarakan perusahaannya dengan melakukan perbuatan-perbuatan menutup persetujuan atas nama atau firma dia sendiri, tetapi atas amanat dan tanggungan orang lain dan dengan menerima upahan atau provisi tertentu. Dalam menjalankan kegiatan usahanya, tugas komisioner ialah menghubungkan pemberi kuasa (prinsipal) dengan pihak ketiga dengan memakai namanya sendiri. Menurut Pasal 77 KUHD menyatakan bahwa komisioner tidak diwajibkan untuk menyebutkan kepada pihak ketiga dengan siapa ia berniaga, yaitu nama orang yang memberi perintah, oleh karena itu hubungan antara komisioner dengan pihak ketiga merupakan tindakan untuk urusan pihak komisioner itu sendiri. Hal tersebut dapat dijadikan dasar dalam melaksanakan kegiatan usaha yaitu pada transaksi digital dengan sistem dropship. 


\section{Hubungan Hukum Dropshipper sebagai Perantara Dagang dalam Perdagangan}

Dalam transaksi digital, para pelaku usaha mengikat dirinya dengan pihak lain dengan perjanjian sebagaimana telah dibuat atas persetujuan kedua belah pihak dan berdasar pada undang-undang yang berlaku. Secara normatif, dalam Pasal 1313 BW disebutkan bahwa: "Persetujuan atau perjanjian ialah suatu perbuatan hukum dimana seseorang atau lebih mengikatkan dirinya terhadap satu orang atau lebih". Mengingat perjanjian membawa akibat hukum bagi para pihak yang membuatnya, maka suatu perjanjian harus memenuhi syarat-syarat sahnya suatu perjanjian. ${ }^{18}$ Berdasarkan Pasal 1320 BW, sahnya suatu perjanjian harus memenuhi empat syarat, yakni adanya:

a. Kesepakatan para pihak;

b. Kecakapan membuat suatu perjanjian;

c. Hal tertentu;

d. Yang diperbolehkan.

Unsur pertama dan kedua yaitu kesepakatan dan kecakapan merupakan syarat subjektif suatu perjanjian, sedangkan unsur ketiga dan keempat yaitu suatu hal tertentu dan sebab yang halal merupakan syarat objektif perjanjian. ${ }^{19}$ Syarat subjektif dalam perjanjian menyebabkan perjanjian tersebut menjadi dapat dibatalkan apabila tidak dipenuhi, sedangkan syarat objektif dalam perjanjian tersebut jika tidak dipenuhi maka perjanjian tersebut batal demi hukum. ${ }^{20}$ Jika keempat syarat sah dalam Pasal 1320 BW tersebut dipenuhi dalam perjanjian jual beli secara online atau digital dengan sistem dropship maka telah terjadi perjanjian di antara mereka yang menimbulkan hubungan hukum yang berakibat timbulnya hak dan kewajiban bagi masing-masing pihak. ${ }^{21}$ Sistem dropship merupakan transaksi digital dengan situs e-commerce yang berdasar pada perjanjian digital atau kontrak elektronik. Perjanjian ataupun kontrak elektronik (e-contract) adalah perjanjian para pihak yang

\footnotetext{
${ }^{18}$ Sentosa Sembiring, Op.Cit.[152].

19 Subekti, Hukum Perjanjian Cetakan ke XX (PT. Intermasa 2004).[17].

${ }^{20}$ Achmad Busro, Hukum Perikatan Berdasarkan Buku III KUH Perdata (Pohon Cahaya 2012).[93].

${ }^{21}$ Bima Prabowo et al., 'Tanggung Jawab Dropshipper Dalam Transaksi E-Commerce Dengan Cara Dropship Ditinjau Dari Undang-Undang Nomor 8 Tahun 1999 Tentang Perlindungan Konsumen'(2016) Volume 5 Nomor 3 Diponegoro Law Journal.[4-5].
} 
dibuat melalui sistem elektronik. ${ }^{22}$ Transaksi digital atau online dalam e-commerce memiliki banyak tipe dan variasi yaitu: ${ }^{23}$

a. Transaksi melalui chatting dan video conference;

b. Transaksi melalui e-mail;

c. Transaksi melalui website atau situs.

\section{Hubungan Hukum Dropshipper dengan Produsen dan/atau Supplier Barang}

Sebagai dropshipper selaku komisioner dalam transaksi jual beli online, dropshipper bertindak atas nama sendiri dan tidak wajib untuk menyebutkan kepada pihak ketiga dengan siapa ia berniaga (nama orang yang memberi perintah). Hal tersebut membuat pihak dropshipper terikat pada pihak lain dalam suatu perikatan atau perjanjian. Mengenai hubungan hukum antara komisioner dengan prinsipal tidak diatur dengan tegas dalam KUHD, maka para pakar berpendapat bahwa hubungan hukum tersebut merupakan pemberian kuasa yang bersifat khusus yaitu terletak pada tindakan komisioner sebagai penerima kuasa menjadi tidak demikian apabila tindakannya untuk dan atas nama dirinya sendiri kepada pembeli atau pihak ketiga. ${ }^{24}$

\section{Hubungan Hukum Dropshipper dengan Pembeli atau Pihak Ketiga}

Transaksi jual beli online dapat dilakukan oleh siapa saja termasuk dropshipper yang merupakan pelaku usaha dimana dalam hal tersebut menawarkan barangnya kepada calon-calon pembeli atau pihak ketiga melalui digital atau e-commerce. Dalam menawarkan suatu barang di e-commerce, dropshipper hanya cukup menampilkan foto berbagai barang dari produsen dan/atau supplier barang pada toko online milik dropshipper. Jika pembeli atau pihak ketiga tertarik dan memutuskan untuk membeli suatu barang dari toko online milik pihak dropshipper, maka dalam hal tersebut terdapat adanya hubungan hukum. Hubungan antara dropshipper dan

\footnotetext{
${ }^{22}$ Undang-Undang Nomor 19 Tahun 2016 Tentang Perubahan Atas Undang-Undang Nomor 11 Tahun 2008 Tentang Informasi dan Transaksi Elektronik, (Lembaran Negara Tahun 2016 Nomor 5952).

${ }^{23}$ Asnawi Haris Fuadi, Transaksi Bisnis E-Commerce Perspektif Islam (Magistra Insania Press 2004).[28].

${ }^{24}$ I Ketut Oka S., Op.Cit.[92].
} 
pembeli atau pihak ketiga merupakan hubungan perjanjian jual beli. Berdasarkan Pasal 1457 BW disebutkan bahwa: "Jual beli adalah suatu persetujuan, dengan mana pihak yang satu mengikat dirinya untuk menyerahkan suatu kebendaan, dan pihak yang lain untuk membayar harga yang telah dijanjikan".

Sedangkan dalam Pasal 1458 BW menyatakan bahwa: "Jual beli itu dianggap telah terjadi antara kedua belah pihak, seketika setelah orang-orang ini mencapai sepakat tentang kebendaan tersebut dan harganya meskipun kebendaan itu belum diserahkan maupun harganya belum dibayar". Ketentuan tentang jual beli dalam BW bahwa kata sepakat merupakan salah satu unsur yang terpenting yaitu kata sepakat tiada lain adalah munculnya hak dan kewajiban pada saat disetujuinya apa yang menjadi objek jual beli. ${ }^{25}$ Berdasarkan Pasal 1457 BW terdapat 2 (dua) unsur dari perjanjian jual beli yakni menyerahkan kebendaan (barang) dan membayar harga (harga). ${ }^{26}$

Berkaitan dengan Pasal 1458 BW menyatakan bahwa perjanjian jual beli telah lahir manakala para pihak telah mencapai sepakat tentang kedua unsur perjanjian jual beli tersebut yaitu kebendaan dan harga. Ketika pihak dropshipper menawarkan barang dan harga kemudian pembeli atau pihak ketiga sepakat untuk melakukan transaksi digital maka lahirlah suatu perjanjian jual beli. Hal tersebut merupakan pencerminan prinsip konsensualisme yaitu terdapat kesesuaian kehendak yang tercermin dari kesepakatan para pihak dalam hal barang dan harga. ${ }^{27}$ Hubungan dropshipper dengan pembeli atau pihak ketiga tidak terpisahkan juga dengan prinsip pacta sunt servanda yaitu berdasarkan Pasal 1338 BW. Hal tersebut mengandung arti bahwa perjanjian yang dibuat oleh para pihak khususnya selaku penjual dan pembeli suatu barang keberlakuannya mengikat bagi para pihak didalamnya saja dan tidak terikat dengan pihak lain manapun. Oleh karena itu, para pihak tidak ada alasan untuk tidak melaksanakan prestasi atau kewajiban dan jika terdapat salah satu pihak tidak melaksanakan prestasi atau kewajiban tersebut yang dapat

\footnotetext{
${ }^{25}$ Sentosa Sembiring, Op.Cit.[160].

${ }^{26}$ Sogar Simamora et al., Hukum Kontrak, Buku Ajar (2012).[45].

${ }^{27}$ ibid. [45-46].
} 
menimbulkan kerugian bagi pihak lain maka disebut dengan wanprestasi atau ingkar janji. ${ }^{28}$

\section{Hubungan Hukum Supplier dan/atau Produsen dan/atau Penjual dengan Jasa Pengiriman Barang}

Supplier dan/atau produsen dan/atau penjual merupakan pengirim barang dalam transaksi digital dengan sistem dropship. Dalam hal tersebut lahirlah suatu hubungan hukum antara supplier dan/atau produsen dan/atau penjual dengan jasa pengiriman barang. Hubungan hukum tersebut menimbulkan suatu perikatan yaitu perjanjian pengangkutan. Pengangkutan yang digunakan dalam sistem dropship ialah ekspeditur yang diatur dalam Pasal 86 KUHD. Ekspeditur merupakan subjek hukum pengangkutan karena mempunyai hubungan yang sangat erat dengan pengirim, pengangkut, serta penerima barang. ${ }^{29}$ Tanggung jawab ekspeditur terhadap barang-barang yang telah diserahkan pengirim kepadanya terdapat pada Pasal 87 KUHD yaitu untuk: ${ }^{30}$

1. Menyelenggarakan pengiriman secepatnya dengan rapi pada barang yang telah diterimanya dari pengirim;

2. Mengindahkan segala upaya untuk menjamin keselamatan barang-barang tersebut;

3. Pengambilan barang-barang dari gudang pengirim;

4. Melakukan penyimpanan di gudang miliknya;

5. Pengambilan barang muatan dari pelabuhan tujuan untuk diserahkan kepada penerima yang berhak atau kepada pengangkut selanjutnya.

Tanggung jawab pengangkut diatur didalam Pasal 91 KUHD dan tanggung jawab pengangkut terhadap keselamatan barang yang diangkut diatur dalam Pasal 468 KUHD. Isi dari kedua pasal tersebut tampak bahwa pengangkut bertanggung jawab terhadap keselamatan barang yang diangkutnya sejak saat ia menerimanya

${ }^{28}$ Yosi Krisharyawan, 'Tinjauan Hukum Mengenai Transaksi Jual-Beli Melalui Situs Belanja Online (Online Shop) Menurut Kitab Undang-Undang Hukum Perdata Dan Undang-Undang Nomor 8 Tahun 1999 Tentang Perlindungan Konsumen'(2015) Edisi 07 Januari-Juni Privat Law. [146].

${ }^{29}$ Fatahillah, 'Pengaturan Perlindungan Hukum Terhadap Pengguna Jasa Transportasi di Darat atas Kehilangan dan Kerusakan Barang Kiriman' (2015) Volume 4 Nomor 1 Jurnal Ilmu Hukum REUSAM.[93].

${ }^{30}$ ibid. 
dari pengirim hingga ia menyerahkan pada penerima barang, pengangkut wajib mengganti kerugian yang ditimbulkan kepada pihak yang dirugikan, apabila kerugian tersebut disebabkan kelalaian atau kesalahan dari pihak pengangkut. ${ }^{31}$

\section{Tanggung Gugat Dropshipper Jika Terdapat Cacat Produk}

Ditinjau dari hukum perlindungan konsumen, tanggung jawab adalah pertanggungjawaban atas hasil produksi berupa suatu barang atau jasa yang dihasilkan oleh perusahaan tertentu, apabila menimbulkan gugatan maka dikenal dengan istilah tanggung gugat yang merupakan istilah untuk gugatan ganti rugi dalam ruang lingkup hukum perdata. ${ }^{32}$ Salah satu Lembaga hukum yang berdimensi internasional yang perlu diperhatikan dalam revisi maupun pembentukan hukum ekonomi nasional adalah tanggung gugat produk (product liability). ${ }^{33}$ Pembeli atau pihak ketiga memiliki hak untuk mendapatkan barang yang sesuai dengan perjanjian khususnya barang tersebut tidak mengandung cacat. Oleh karena itu pelaku usaha baik produsen maupun dropshipper selaku penjual wajib bersikap cermat dan berhati-hati (adagium caveat venditor) ${ }^{34}$ agar tidak mendatangkan kerugian bagi pembeli atau pihak ketiga. Hal demikian yang menyebabkan product liability sebagai instrumen hukum perlindungan konsumen lahir. ${ }^{35}$ Dalam pengajuan gugatan pada product liability dapat dilakukan berdasarkan 3 (tiga) hal yaitu melanggar jaminan (breach of warranty), terdapat unsur kelalaian (negligence), menerapkan tanggung gugat mutlak (strict liability). ${ }^{36}$ Sistem tanggung gugat dalam product liability berlaku prinsip tanggung gugat mutlak (strict liability). Dalam sistem dropship, dropshipper harus bertanggung jawab atas barang yang dijual pada pembeli atau pihak ketiga yang merasa dirugikan karena pembeli atau pihak ketiga hanya dapat

\footnotetext{
${ }^{31}$ ibid.[96-97].

${ }^{32}$ M.Khoidin, Tanggung Gugat dalam Hukum Perdata (Laksbang Justitia 2020).[17].

${ }^{33}$ J. Widijantoro, Product Liability dan Perlindungan Konsumen di Indonesia (Justitia Et Pax 1998).[5].

${ }^{34}$ Celina Tri S.K., Hukum Perlindungan Konsumen (Sinar Grafika 2019).[100].

${ }^{35}$ John Pieris dan Wiwik Sri Widiarty, Negara Hukum dan Perlindungan Konsumen terhadap Produk Pangan Kadaluarsa (Pelangi Cendekia 2017).[86].

${ }^{36}$ Celina Tri S.K., Op.Cit.[97].
} 
complain pada pihak dropshipper. Berdasarkan Pasal 19 ayat (5) Undang-Undang Nomor 8 Tahun 1999 tentang Perlindungan Konsumen selanjutnya disebut sebagai UUPK menyatakan bahwa terdapat pengecualian bagi pihak pelaku usaha yang dibebaskan untuk memberikan ganti rugi apabila pelaku usaha dapat membuktikan bahwa kesalahan tersebut bukan kesalahannya melainkan kesalahan pihak pembeli atau pihak ketiga.

\section{Tanggung Gugat Berdasarkan Wanprestasi dan Perbuatan Melanggar Hukum}

Dropshipper yang tidak melakukan prestasinya dan melanggar perjanjian yang telah dibuat oleh para pihak pada kontrak elektronik maka dapat digugat atas dasar wanprestasi. Misalnya, dropshipper tidak menyerahkan barang setelah menerima pembayaran atau barang yang dikirim tidak sesuai dengan foto yang ditawarkan pada toko online milik dropshipper. Hal tersebut dapat dikualifikasikan sebagai wanprestasi dan pihak yang dirugikan dapat menuntut ganti rugi sebagaimana ketentuan wanprestasi diatur dalam Pasal 1243 BW. Terdapat dua alternatif dalam akibat dari suatu wanprestasi, yang pertama yaitu para pihak tetap melanjutkan perjanjian dengan meminta ganti rugi dan yang kedua yaitu para pihak membatalkan perjanjian dengan tetap meminta ganti rugi. ${ }^{37}$ Dari akibat hukum tersebut, menurut Subekti terdapat empat macam wanprestasi antara lain: ${ }^{38}$

1. Tidak menyanggupi prestasi sama sekali meskipun mampu;

2. Memenuhi prestasi tetapi tidak tepat waktunya atau terlambat;

3. Memenuhi prestasi tetapi tidak sesuai atau keliru;

4. Melakukan sesuatu yang menurut perjanjian tidak boleh dilakukan.

Dari keempat macam wanprestasi, dapat dikualifikasikan bahwa gugatan yang tepat dalam transaksi jual beli online adalah gugatan wanprestasi dengan merujuk pada kewajiban-kewajiban dropshipper dalam kontrak elektronik yang telah dilanggar dan karenanya menimbulkan kerugian.

Dasar gugatan perbuatan melawan hukum yaitu kepentingan pihak tertentu yang dirugikan oleh perbuatan pihak lainnya meskipun tidak terdapat adanya

\footnotetext{
${ }^{37}$ ibid. [39].
}

38 ibid. 
suatu hubungan hukum keperdataan yang bersifat kontraktual (perjanjian). ${ }^{39}$ Tuntutan ganti rugi pada gugatan perbuatan melawan hukum didasarkan pada hitungan objektif dan konkrit yang meliputi kerugian materiil dan immaterial, serta berupa pemulihan pada keadaan semula sehingga tidak perlu menyebutkan bagaimana bentuk ganti rugi dan juga tidak perlu rincian sebagaimana dimaksud dalam Pasal $1365 \mathrm{BW} .{ }^{40}$ Berbeda halnya dengan gugatan wanprestasi yang diatur dalam Pasal 1246 BW bahwa ganti rugi yang dapat dituntut haruslah terinci dan jelas sehingga ketentuan tersebut yang dijadikan dasar oleh kreditur untuk menuntut ganti kerugian. ${ }^{41}$

\section{Tanggung Gugat Terhadap Cacat Tersembunyi}

Cacat tersembunyi adalah suatu keadaan barang yang cacatnya atau ketidaksempurnaannya tidak terlihat dari luar yang diserahkan penjual kepada pembeli dianggap sebagai orang yang tidak mempermasalahkan hal tersebut dan apabila hal itu diketahui sebelum kesepakatan akan menjadi tidak tercapai kesepakatan dari pihaknya. ${ }^{42}$ Apabila terdapat cacat tersembunyi maka pihak dropshipper memiliki tanggung gugat pada pembeli atau pihak ketiga terhadap produk yang dijual. Hal tersebut terjadi karena adanya hubungan hukum antara dropshipper dan pembeli atau pihak ketiga dalam transaksi jual beli secara online. Selanjutnya, dropshipper akan menindaklanjuti hal tersebut kepada pihak supplier untuk penggantian biaya atas cacat produk. Dengan demikian, pelaku usaha baik dropshipper maupun supplier bertanggung gugat atas adanya cacat tersembunyi pada produk yang dijual. Berdasarkan hal tersebut, kerugian yang diderita pembeli atau pihak ketiga berupa kelalaian dropshipper dalam melaksanakan pelayanan jual beli secara online merupakan tanggung jawab yang dibebankan pada pihak

\footnotetext{
${ }^{39}$ Suwari Akhmaddhian dan Asri Agustiwi, 'Perlindungan Hukum Terhadap Konsumen Dalam Transaksi Jual Beli Secara Elektronik di Indonesia’ (2016) Volume 3 Nomor 2 Jurnal Unifikasi.[52].

${ }^{40}$ M.Khoidin, Op.Cit.[110].

${ }^{41}$ ibid.

${ }^{42}$ I Ketut Oka, Op.Cit.[76].
} 
dropshipper selaku pelaku usaha. Pada dasarnya mengenai ketersediaan barang dengan rinciannya yang dipaparkan dalam sebuah aplikasi jual beli secara online berupa by whatsapp, by instagram, by web, dan by platform e-commerce berada dalam tanggung jawab pihak dropshipper selaku penjual barang. Hal tersebut sudah sepatutnya dibebankan pada pihak dropshipper karena selama proses transaksi digital yang berhubungan dan/atau berhadapan langsung dengan pihak pembeli dan/ atau pihak ketiga yaitu hanyalah pihak penjual. Menurut Pasal 1504 BW, penjual diwajibkan untuk menanggung terhadap cacat tersembunyi pada barang yang dijual yang membuat barang tersebut kehilangan fungsi sehingga barang tersebut tidak dapat digunakan sebagaimana mestinya.

\section{Tanggung Gugat Pihak Lain dalam Transaksi Jual Beli Secara Online dengan}

\section{Sistem Dropship}

Pada pihak perbankan, Berdasarkan Pasal 34 ayat (2) huruf b Peraturan Bank Indonesia Nomor 20/6/PBI/2018 tentang Uang Elektronik selanjutnya disebut sebagai PBI No. 20/6/PBI/2018 menyatakan bahwa penerbit e-money wajib mengutamakan prinsip perlindungan konsumen yaitu khususnya bagi penggunanya. Apabila dalam pelaksanaan mekanisme tersebut terdapat kelalaian atau kesalahan dari pihak penerbit dapat dituntut ganti kerugian finansial yang didasarkan sebagaimana dimaksud dalam Pasal 43 ayat (2) huruf c PBI No 20/6/ PBI/2018 tentang Uang Elektronik dan apabila sebaliknya yaitu terdapat kelalaian atau kesalahan dari pihak pengguna dan/atau pemegang uang elektronik tersebut maka perihal kerugian tidak diatur secara tegas dalam peraturan tersebut. ${ }^{43}$ Selain itu, dalam rangka memberikan perlindungan hukum terhadap pengguna uang elektronik maka Bank Indonesia telah mengeluarkan Peraturan Bank Indonesia Nomor 16/1/PBI/2014 tentang Perlindungan Konsumen Jasa Sistem Pembayaran dan lebih lanjut Otoritas Jasa Keuangan juga mengeluarkan peraturan tentang

\footnotetext{
${ }^{43}$ Dian Barry W. dan I Wayan Parsa, 'Tanggung Jawab Penerbit E-Money Sebagai Alat Pembayaran Non Tunai Apabila Terjadi Kerugian Pada Pengguna E-Money’ (2020) Volume 8 Nomor 4 Jurnal Kertha Desa.[74].
} 
Perlindungan Konsumen Sektor Jasa Keuangan Nomor 1/POJK.07/2013. Dengan demikian penerbit dapat diminta pertanggung jawaban sepanjang kerugian yang disebabkan atas kelalaian dan kesalahan bukan dari pihak pengguna karena mengingat hubungan hukum yang terjadi antara penerbit dan pengguna bersifat jual beli dan kedudukan pengguna bukanlah sebagai nasabah melainkan sebagai konsumen dan/atau pembeli. Tuntutan atas ganti kerugian sejumlah nilai uang yang terdapat di dalam kartu akibat dari penggunaan transaksi pembayaran yang tidak benar tidak dapat dilakukan karena telah berakhir hubungan hukum antara penjual dan pembeli setelah dilakukan transaksi jual beli. ${ }^{44}$

Pada pihak jasa pengiriman barang yaitu ekspeditur, menurut Pasal 87 dan Pasal 88 KUHD, ekspeditur bertanggung jawab hanya sebatas barang yang akan dikirim tersebut telah diterima oleh pihak pengangkut dan apabila barang tersebut terdapat kerusakan dan dapat dibuktikan atas kesalahan atau kelalaian pihak ekspeditur ketika barang tersebut masih ada pada pihak ekspeditur, maka pihak ekspeditur dapat dituntut untuk mengganti kerugian yang terjadi. ${ }^{45}$

\section{Kesimpulan}

Perdagangan dunia digital telah melahirkan suatu model bisnis baru dalam hal ini juga membutuhkan peran perantara dalam kegiatan usaha yang disebut sebagai sistem dropship. Dalam transaksi digital dibutuhkan peran para pelaku usaha dropshipper sebagai sarana penunjang promosi suatu produk di kalangan masyarakat luas baik dalam negeri maupun luar negeri, sehingga menimbulkan adanya hubungan hukum keperantaraan yang saling menguntungkan bagi industri perdagangan terkini. Dengan adanya situs e-commerce tentu para pelaku usaha wajib membuat kontrak perdagangan secara online atau biasa disebut dengan kontrak digital atau kontrak elektronik. Hubungan keperantaraan dropship masuk

${ }^{44}$ ibid. [75-76].

${ }^{45}$ Satria Adjie Bayu P., Tanggung Gugat Perusahaan Jasa Pengiriman Barang Terhadap Konsumen Yang Kehilangan Barang Ditinjau Dari UU No. 8 Tahun 1999 Tentang Perlindungan Konsumen (Studi Kasus Di BPSK Kota Surabaya) (2012) Skripsi, Program Sarjana Universitas Pembangunan Nasional "Veteran" Jawa Timur.[16-17]. 
dalam kategori pedagang perantara berdiri sendiri yang disebut komisioner. Peran perantara dagang seperti komisioner sangatlah penting sehingga dropshipper selaku komisioner berkewajiban menjalankan kegiatan usaha dengan atas nama dirinya sendiri baik dari proses penawaran barang pada media sosial hingga pada barang yang telah diorderkan kepada produsen dan/atau supplier. Hubungan antara dropshipper dan pembeli atau pihak ketiga merupakan hubungan perjanjian jual beli berdasarkan Pasal 1457 BW.

Dropshipper harus bertanggung gugat atas barang yang dijual pada pembeli atau pihak ketiga yang merasa dirugikan. Pembeli atau pihak ketiga hanya dapat complain pada pihak dropshipper. Dalam hukum perdata, complain tersebut dikenal dengan istilah tanggung gugat yaitu tanggung gugat berdasarkan wanprestasi dan tanggung gugat atas dasar perbuatan melanggar hukum. Dropshipper yang tidak melakukan prestasinya dan melanggar perjanjian yang telah dibuat oleh para pihak pada kontrak elektronik maka dapat digugat atas dasar wanprestasi. Pihak yang dirugikan dapat menuntut ganti rugi sebagaimana ketentuan wanprestasi diatur dalam Pasal 1243 BW. Dengan demikian gugatan yang tepat dalam transaksi jual beli online adalah gugatan wanprestasi dengan merujuk pada kewajiban-kewajiban dropshipper dalam kontrak elektronik yang telah dilanggar dan karenanya menimbulkan kerugian.

Pelaku usaha baik dropshipper maupun supplier bertanggung gugat atas adanya cacat tersembunyi pada produk yang dijual. Berdasarkan hal tersebut, kerugian yang diderita pembeli atau pihak ketiga berupa kelalaian dropshipper dalam melaksanakan pelayanan jual beli secara online merupakan tanggung jawab yang dibebankan pada pihak dropshipper selaku pelaku usaha.

\section{Daftar Bacaan}

\section{Buku}

Achmad Busro, Hukum Perikatan Berdasarkan Buku III KUH Perdata (Pohon Cahaya 2012).

Adi Nugroho, E-commerce Memahami Perdagangan di Dunia Maya Cet.1 
(Informatika 2006).

Andi Sri R.W., Buku Ajar Hukum Dagang (Mitra Wacana Media 2014).

Asnawi, Haris Faulidi, Transaksi Bisnis E-Commerce Persfektif Islam (Magistra Insania Press 2004).

Asnawi Haris Fuadi, Transaksi Bisnis E-Commerce Perspektif Islam (Magistra Insania Press 2004).

Celina Tri Siwi Kristiyanti, Hukum Perlindungan Konsumen (Sinar Grafika 2019).

John Pieris dan Wiwik Sri Widiarty, Negara Hukum dan Perlindungan Konsumen terhadap Produk Pangan Kadaluarsa (Pelangi Cendekia 2017).

J. Widijantoro, Product Liability dan Perlindungan Konsumen di Indonesia (Justitia Et Pax 1998).

Mark Hayes and Andrew Youderian, The Ultimade Guide to Dropshipping, 1 st edition (Lulu Publishing Services 2013).

M. Khoidin, Tanggung Gugat dalam Hukum Perdata (Laksbang Justitia 2020).

Rico Huang dan Seno A. Airlangga, Menjual Barang Tanpa Tatap Muka Dropship Mastery (PT. Alona Indonesia Raya 2014).

R. Soekardono, Hukum Dagang Indonesia (Soeroengan 1963).

Sentosa Sembiring, Hukum Dagang Edisi Revisi Cetakan Keempat (PT. Citra Aditya Bakti 2015).

Sogar Simamora, et al., Hukum Kontrak Buku Ajar (Tidak Diterbitkan 2012).

Subekti, Hukum Perjanjian Cetakan ke XX (PT. Intermasa 2004).

\section{Jurnal}

Bima Prabowo et al., 'Tanggung Jawab Dropshipper Dalam Transaksi E-Commerce Dengan Cara Dropship Ditinjau Dari Undang-Undang Nomor 8 Tahun 1999 Tentang Perlindungan Konsumen' (2016) Diponegoro Law Journal.

Dian Barry W. dan I Wayan Parsa, 'Tanggung Jawab Penerbit E-Money Sebagai Alat Pembayaran Non Tunai Apabila Terjadi Kerugian Pada Pengguna E-Money’ (2020) Jurnal Kertha Desa. 
Fatahillah, 'Pengaturan Perlindungan Hukum Terhadap Pengguna Jasa Transportasi di Darat atas Kehilangan dan Kerusakan Barang Kiriman'(2015) Jurnal Ilmu Hukum REUSAM.

I Ketut Oka S., 'Tanggung Jawab Pedagang Perantara Terhadap Pihak Ketiga Menurut Hukum Jual Beli’ (2014) Jurnal Law Review.

Mohammad Fadil, 'Kajian Yuridis Praktik Dropship Online Shop di Indonesia Dalam Perspektif Hukum Ekonomi Syariah, (2017) Skripsi, Program Sarjana Universitas Negeri Semarang.

Satria Adjie Bayu P., 'Tanggung Gugat Perusahaan Jasa Pengiriman Barang Terhadap Konsumen Yang Kehilangan Barang Ditinjau Dari UU No. 8 Tahun 1999 Tentang Perlindungan Konsumen (Studi Kasus Di BPSK Kota Surabaya)', (2012) Skripsi, Program Sarjana Universitas Pembangunan Nasional "Veteran" Jawa Timur.

Suwari Akhmaddhian dan Asri Agustiwi, 'Perlindungan Hukum Terhadap Konsumen Dalam Transaksi Jual Beli Secara Elektronik di Indonesia' (2016) Jurnal Unifikasi.

Yosi Krisharyawan, 'Tinjauan Hukum Mengenai Transaksi Jual-Beli Melalui Situs Belanja Online (Online Shop) Menurut Kitab Undang-Undang Hukum Perdata Dan Undang-Undang Nomor 8 Tahun 1999 Tentang Perlindungan Konsumen' (2015) Privat Law.

\section{Laman}

Databoks, 'Transaksi E-Commerce Indonesia Naik 500\% Dalam 5 Tahun', <https:// databoks.katadata.co.id/datapublish/2016/11/16/transaksi-e-commerceindonesia-naik-500-dalam-5-tahun>, 16 November 2016, dikunjungi pada tanggal 25 Agustus 2020.

Erlangga Jumena, 'Ini Aturan yang Harus Dicermati Pebisnis Online', <https:// money.kompas.com/read/2014/08/22/203200426/Ini.Aturan.yang.Harus. Dicermati.Pebisnis.Online>, 22 Agustus 2014, dikunjungi pada tanggal 31 Agustus 2020.

Marcel Susanto, 'Apa Itu Revolusi Industri 4.0?', <https://www.zenius.net/ blog/21104/revolusi-industri-4-0>, 18 Januari 2019, dikunjungi pada tanggal 02 September 2020.

\section{Peraturan Perundang-undangan}

Kitab Undang-Undang Hukum Perdata (Burgerlijk Wetboek). 
Kitab Undang-Undang Hukum Dagang.

Undang-Undang Nomor 8 Tahun 1999 tentang Perlindungan Konsumen, (Lembaran Negara Republik Indonesia Tahun 1999 Nomor 42, Tambahan Lembaran Negara Nomor 3821).

Peraturan Menteri Perdagangan Republik Indonesia Nomor 32/M-Dag/Per/8/2008 tentang Penyelenggaraan Kegiatan Usaha Perdagangan dengan Sistem Penjualan Langsung.

Peraturan Otoritas Jasa Keuangan Nomor 1/POJK.07/2013 tentang Perlindungan Konsumen Sektor Jasa Keuangan.

Peraturan Bank Indonesia Nomor 16/1/PBI/2014 tentang Perlindungan Konsumen Jasa Sistem Pembayaran.

Peraturan Bank Indonesia Nomor 20/6/PBI/2018 tentang Uang Elektronik.

Peraturan Pemerintah Nomor 71 Tahun 2019 tentang Penyelenggaraan Sistem dan Transaksi Elektronik. 